\title{
STRATEGI PENGEMBANGAN USAHATANI BAWANG PUTIH DI KECAMATAN CIWIDEY KABUPATEN BANDUNG
}

\section{DEVELOPMENT STRATEGY OF WHITE ONION FARMING IN CIWIDEY DISTRICT, BANDUNG REGENCY}

\author{
Syam Ahmad Sopian*, Lucyana Trimo \\ Program Studi Ekonomi Pertanian Universitas Padjadjaran, Kampus Jatinangor \\ *Email: ahmadsamsopian@gmail.com \\ (Diterima 16-06-2020; Disetujui 16-07-2020)
}

\begin{abstract}
ABSTRAK
Produksi bawang putih di Indonesia dapat dinilai belum stabil dan masih jauh di bawah kebutuhan pasar. Produksi bawang putih tahun 2017 di Indonesia sebesar 19.510 ton. Hasil produksi tersebut menurun dari total produksi bawang putih pada tahun 2016 yang mencapai 21.150 ton. Jumlah produksi bawang putih tersebut masih belum mampu memenuhi kebutuhan masyarakat Indonesia yang mencapai 500.000 ton/tahun (Kementan, 2017). Sementara itu, kebutuhan konsumsi bawang putih di Indonesia dari tahun ke tahun terus meningkat sejalan dengan meningkatnya jumlah penduduk. Namun demikian, peningkatan ini belum mampu diimbangi dengan peningkatan produksi dalam negeri. Untuk itu perlu dilakukan suatu kajian prospek pengembangan bawang putih di lokasi sentra salah satunya di Kecamatan Ciwidey Kabupaten Bandung. Penelitian ini bertujuan: (1) mendeskripsikan usahatani bawang putih ditinjau dari aspek teknis, ekonomi dan social, dan (2) merancang alternatif strategi pengembangan bawang putih. Lokasi penelitian di Kecamatan Ciwidey Kabupaten Bandung yang dipilih secara sengaja karena merupakan sentra sayuran dataran tinggi dan pernah menjadi produsen bawang putih. Hasil penelitian menunjukkan bahwa kondisi lingkungan di Ciwidey sesuai dengan syarat pertumbuhan tanaman bawang putih, secara ekonomi usahatani bawang putih di Kecamatan Ciwidey dapat dikatakan masih layak diusahakan dilihat dari nilai $\mathrm{R} / \mathrm{C}$ sebesar 1,24 yang artinya masih dapat memberikan keuntungan. Rekomendasi strategi yang disarankan adalah strategi agresif sebab berusahatani bawang putih di Kecamatan Ciwidey menunjukkan yang sangat menguntungkan karena memiliki kekuatan untuk memanfaatkan peluang yang ada. Oleh karena itu, strategi yang tepat dan diutamakan dalam upaya pengembangan usahatani bawang putih di Kecamatan Ciwidey adalah dengan meningkatkan produksi bawang putih secara terpadu dengan cara perluasan areal tanam, pemberdayaan kelompok tani serta penumbuhan penangkar benih guna menyediakan kebutuhan benih bawang putih yang berkualitas.
\end{abstract}

Kata kunci: Bawang Putih, Prospek, Strategi, Usahatani

\section{ABSTRACT}

Garlic production in Indonesia can be judged to be unstable and far below market needs. Garlic production in 2017 in Indonesia is 19,510 tons. The production yield decreased from total garlic production in 2016 which reached 21,150 tons. The amount of garlic production is still unable to meet the needs of the Indonesian people who reach 500,000 tons / year (Kementan, 2017). Meanwhile, the need for consumption of garlic in Indonesia from year to year continues to increase in line with the increasing population. However, this increase has not been able to offset the increase in domestic production. For this reason, it is necessary to study a prospect of developing garlic at a central location, one of which is in Ciwidey District, Bandung Regency. This research aim to 1) describe of garlic farming from technical, economic, and social aspects 2) design alternative development strategy for garlic. The research location in Ciwidey District Bandung Regency is purposefully choosen because it is highland vegetable central and ever become garlic producent. The result shows that environmental condition in Ciwidey suits the requirements for 
garlic to grow, garlic farming in Ciwidey District is still worthy to be endevored economically because of the $R / C$ value that is 1,24 which means still can be benefitting. On the other hand, farmer perception can be categorized positive which means they have the hope to developt to developt garlic farming. The recommended strategy is agressive strategy because garlic farming in Ciwidey District appears to be very benefitting because of the power to maximize the existing opportunies. Therefore, the right strategy and should be preferred in the attempt to developt garlic farming in Ciwidey District is to increase the production of garlic in integrated way with expanding the planning areal, empowering farmer groups, and growing seed breeder to provide the needs of high quality garlic seeds.

Keywords: garlic, prospect, strategy, farming

\section{PENDAHULUAN}

$\begin{array}{lcr}\begin{array}{r}\text { Sektor } \\ \text { pertanian }\end{array} \text { di } & \text { negara } \\ \text { merupakan } & \text { sektor utama } & \text { dalam } \\ \text { penyediaan } & \text { kebutuhan } & \text { pangan } \\ \text { masyarakat } & \text { luas, salah } & \text { satunya yaitu } \\ \text { tanaman } & \text { hortikultura. } & \text { Subsektor } \\ \text { hortikultura } & \text { saat ini memiliki peran } \\ \text { penting sebagai pengungkit pertumbuhan } \\ \text { ekonomi di Indonesia di samping sebagai } \\ \text { sumber peningkatan kesejahteraan }\end{array}$
petani.Subsektor hortikultura dalam beberapa kasus komoditas juga telah dapat meningkatkan pendapatan petani karena merupakan penyedia lapangan pekerjaan, yang lebih lanjut dapat mengurangi kemiskinan dan meningkatkan ketahanan pangan, khususnya di daerah dataran tinggi yang berada di Indonesia (Saragih dalam Ulfa, 2018).

Pertumbuhan populasi Indonesia terus meningkat yang mengarah pada peningkatan permintaan untuk berbagai komoditas pertanian. Padahal, produksi komoditas pertanian Indonesia tidak mencukupi permintaan komoditas yang menyebabkan defisit pasokan. Salah satu komoditas pertanian yang mengalami kondisi tersebut adalah bawang putih. Kebutuhan konsumsi bawang putih di Indonesia dari tahun ke tahun terus meningkat sejalan dengan meningkatnya jumlah penduduk. Namun demikian, peningkatan ini belum mampu diimbangi dengan peningkatan produksi dalam negeri.

Produksi bawang putih di Indonesia dapat dinilai belum stabil dan masih jauh di bawah kebutuhan pasar. Produksi bawang putih tahun 2017 di Indonesia sebesar 19.510 ton. Hasil produksi tersebut menurun dari total produksi bawang putih pada tahun 2016 yang mencapai 21.150 ton. Jumlah produksi bawang putih tersebut masih belum mampu memenuhi kebutuhan masyarakat 
Indonesia yang mencapai 500.000 ton/tahun (Kementan, 2018).

Tabel 1. Produksi bawang putih di Indonesia tiga tahun terakhir

\begin{tabular}{llll}
\hline Tahun & 2015 & 2016 & 2017 \\
\hline Produksi (ton) & 20.293 & 21.150 & 19.510 \\
\hline Sumber: BPS, 2018
\end{tabular}

Terjadinya ketimpangan antara produksi dan kebutuhan bawang putih nasional memaksa pemerintah untuk melakukan impor setiap tahun. Perkembangan impor bawang putih Indonesia dalam kurun waktu 20 tahun (1996-2016) berfluktuasi dengan kecenderungan terus meningkat. Pada tahun 1996 impor bawang putih Indonesia 59,893 ton, sedangkan pada tahun 2016 mencapai 488,88 ton (BPS, 2017).

Impor bawang putih Indonesia tidak menunjukkan tanda-tanda tren penurunan, sementara itu produksi menunjukkan tanda-tanda sebaliknya. Kondisi kontradiktif ini akan terus terjadi jika pemerintah tidak segera mengambil kebijakan untuk meningkatkan produksi bawang putih dalam negeri. Salah satu kebijakan yang diambil pemerintah dalam mengatasi masalah tersebut adalah pengembangan usahatani bawang putih di lokasi sentra.

Kecamatan Ciwidey merupakan sentra tanaman hortikultura khususnya sayuran dataran tinggi di Kabupaten Bandung. Sebagai daerah sentra sayuran Ciwidey memiliki keunggulan, antara lain potensi lahan yang masih cukup luas serta kesesuaian lingkungan yang sesuai untuk usahatani komoditas sayuran dataran tinggi termasuk bawang putih. Bawang putih dapat tumbuh dengan baik di daerah dingin dengan ketinggian 700 - $1.100 \mathrm{~m} \mathrm{dpl} \mathrm{(di} \mathrm{atas} \mathrm{permukaan} \mathrm{laut)}$ dengan suhu rata-rata $20^{\circ} \mathrm{C}-25^{\circ} \mathrm{C}$, dan memiliki curah hujan rata-rata 1.200 $2.400 \mathrm{~mm}$ per tahun serta tekstur tanah yang gembur dan subur.

Selain memiliki keunggulan dalam sumberdaya alam, Ciwidey juga memiliki keunggulan dalam sumberdaya manusia, karena sebagian besar penduduk memiliki mata pencaharian sebagai petani yang sudah dijalankan secara turun temurun.

Meskipun memiliki keunggulankeunggulan tersebut, saat ini sulit sekali menemukan bawang putih yang diproduksi oleh petani Ciwidey, karena mereka lebih tertarik untuk mengembangkan komoditas lain seperti bawang daun, cabai, wortel dan strawberry dengan alasan lebih menguntungkan.

Sehingga dalam upaya pengembangan usahatani bawang putih perlu 
diperhatikan beberapa aspek mencakup aspek teknis (kesesuaian lingkungan dan penerapan teknik budidaya), aspek kelayakan ekonomi, aspek sosial serta aspek pendukung (kebijakan pemerintah, sarana dan prasarana). Setelah mengetahui mengetahui aspek apa saja yang menjadi potensi maupun peluang dan ancaman maka dapat ditentukan strategi yang paling tepat untuk diterapkan di Kecamatan Ciwidey dalam pengembangan usahatani bawang putih.

\section{METODE PENELITIAN}

Penelitian ini dilaksanakan pada bulan Oktober 2018 sampai dengan Januari 2019 bertempat di Kecamatan Ciwidey Kabupaten Bandung. Lokasi tersebut dipilih dengan pertimbangan bahwa Kecamatan Ciwidey merupakan sentra bawang putih di Jawa Barat, dan saat ini terpilih sebagai daerah penopang untuk swasembada bawang putih nasional. Penelitian ini dilakukan menggunakan metode pendekatan kualitatif dengan teknik penelitian studi kasus (case study). Teknik yang dilakukan dalam pengumpulan data dilaksanakan dengan menggunakan teknik triangulasi. Menurut Sugiyono (2011), triangulasi diartikan sebagai teknik pengumpulan data dan sumberdata yang telah ada. Dalam teknik triangulasi, peneliti menggunakan teknik data yang berbeda-beda untuk mendapatkan data dari sumber yang sama. Peneliti menggunakan observasi partisipatif, wawancara mendalam, dan dokumentasi. Pengamatan dan variabel yang diamati dalam penelitian ini meliputi kesesuaian lingkungan biofisik, penerapan teknologi budidaya, kelayakan usahatani dengan metode $\mathrm{R} / \mathrm{C}$, serta penilaian persepsi petani yang kemudian ditentukan faktor internal dan internal usahatani untuk menyusun rekomendasi pengembangan usahatani bawang putih. Data yang diperoleh kemudian dianalisis berdasarkan tujuan penelitian, yaitu: (1) Untuk menjawab tujuan pertama, dianalisis dengan pendekatan deskriptif kualitatif, yang dilakukan untuk memperoleh informasi tentang usahatani bawang putih, meliputi kesesuaian lingkungan biofisik, penerapan teknologi budidaya, kelayakan usahatani serta penilaian persepsi petani, dan (2) Untuk menjawab tujuan kedua dilakukan alat analisis SWOT yaitu suatu analisis mengenai faktor internal usaha berupa kekuatan (strengths), kelemahan (weaknesses), dan faktor eksternal berupa peluang (opportunities) dan tantangan (threats). Analisis SWOT dilakukan 
untuk mengidentifikasi peluang dan tantangan serta merumuskan strategistrategi dalam menjalankan usahatani bawang putih di Kecamatan Ciwidey, dengan model matriks seperti pada Tabel 2.

Tabel 2. Matriks SWOT

\begin{tabular}{lcc}
\hline & STRENGHTS (S) & WEAKNESSES (W) \\
& Daftar Kekuatan & Daftar Kelemahan \\
\hline OPPORTUNITIES & STRATEGI S-O & STRATEGI \\
(O) & Menciptakan strategi yang & W-O \\
Daftar Peluang & menggunakan kekuatan untuk & $\begin{array}{c}\text { Menciptakan strategi yang meminimalkan } \\
\text { kelemahan untuk memanfaatkan peluang }\end{array}$ \\
\hline THREATS (T) & STRATEGI S-T & STRATEGI \\
Daftar Ancaman & Menciptakan strategi yang & W-T \\
& menggunakan kekuatan untuk & Menciptakan strategi yang meminimalkan \\
& mengatasi ancaman & dan menghindari ancaman \\
\hline
\end{tabular}

- Strategi SO

Strategi ini bersifat agresif, yaitu memaksimalkan kekuatan yang dimiliki untuk memanfaatkan peluang yang ada. Strategi ini direkomendasikan agar perusahaan dapat bersaing dalam suatu industri yang sedang tumbuh dan diharapkan terus tumbuh cukup tinggi.

- Strategi ST

Strategi ini bersifat diversifikasi, yaitu strategi yang memanfaatkan kekuatan yang dimiliki untuk menghadapi ancaman.

- Strategi WO

Strategi ini bersifat intensif, yaitu strategi yang memanfaatkan peluang yang ada dengan cara meminimalkan kelemahan yang ada.

- Strategi WT

Strategi ini bersifat defensif, yaitu strategi yang dilakukan untuk mengatasi ancaman yang ada dan kelemahan yang dimiliki.

HASIL DAN PEMBAHASAN

Sejarah Usahatani Bawang Putih di Kecamatan Ciwidey

Pada tahun 1980an Kecamatan Ciwidey Kabupaten Bandung pernah menjadi salah satu sentra bawang putih nasional yang memasok kebutuhan bawang putih ke pasar-pasar di Kota Bandung dan Kawasan Jabodetabek. Pada saat itu hampir seluruh petani menanam bawang putih karena memiliki nilai ekonomi yang sangat tinggi. Bahkan bawang putih mendapat julukan sebagai berlian putih (white diamonds) karena selain mudah dijual, juga dapat dijadikan sebagai barang investasi yang dapat disimpan lama dan memiliki kecenderungan harga dan permintaan yang terus meningkat. 


\section{STRATEGI PENGEMBANGAN USAHATANI BAWANG PUTIH \\ DI KECAMATAN CIWIDEY KABUPATEN BANDUNG \\ Syam Ahmad Sopian, Lucyana Trimo}

Kelangkaan bawang putih di Ciwidey mulai terjadi sejak tahun 1996, saat itu pasar mulai dibanjiri dengan bawang putih impor dari China (petani biasa menyebutnya bawang kating). Bawang putih lokal pun kalah saing, karena harga bawang kating jauh lebih murah dari bawang putih lokal. Selain itu, penampilan bawang kating lebih menarik buat konsumen karena warnanya yang putih bersih dan siungnya besarbesar. Kebijakan pemerintah yang membuka keran impor seluas-luasnya sampai saat ini membuat petani bawang putih mulai bergeser minatnya ke komoditas lain yang lebih menguntungkan. Sejak saat itu bawang putih mulai lokal mulai sulit ditemui di Ciwidey dan Ciwidey kehilangan pamornya sebagai sentra bawang putih. Saat ini Ciwidey lebih dikenal sebagai sentra sayuran dan juga strawberi.

Minat petani Ciwidey untuk menanam bawang putih umbi mulai menggeliat seiring dengan dicanangkannya program Swaswembada
Bawang Putih Nasional oleh Kementerian Pertanian. Tujuan dari program ini yaitu untuk mengurangi ketergantungan terhadap bawang putih impor dan merangsang minat petani untuk kembali menanam bawang putih. Beberapa kegiatan dilaksanakan oleh instansi terkait untuk program ini diantaranya pelatihan budidaya bawang putih oleh BBPP Lembang bekerja sama dengan Kopontren al-Ittifaq, perbanyakan benih sumber bawang putih oleh Balai Penelitian Sayuran serta pengembangan benih bawang putih oleh Dinas Pertanian Kabupaten Bandung.

\section{Kesesuaian Lingkungan Biofisik}

Berdasarkan hasil penelitian di lapangan terhadap kondisi lingkungan biofisik dan dibandingkan dengan syarat tumbuh tanaman bawang putih berdasarkan literatur serta penelitian terdahulu maka secara teknis wilayah Kecamatan Ciwidey dapat dikategorikan cocok untuk pengembangan bawang putih.

Tabel 3. Perbandingan syarat tumbuh bawang putih dengan kondisi lingkungan biofisik di Kecamatan Ciwidey dengan literatur

\begin{tabular}{|c|c|c|c|}
\hline No & $\begin{array}{l}\text { Syarat tumbuh menurut BPTP Jatim, } \\
2018\end{array}$ & Kondisi di Kec. Ciwidey & Keterangan \\
\hline 1 & Berada pada ketinggian di atas $600 \mathrm{mdpl}$ & $\begin{array}{l}\text { Berada pada ketinggian } 1.050-1.400 \\
\text { mdpl }\end{array}$ & sesuai \\
\hline 2 & Suhu harian berkisar $15^{\circ} \mathrm{C}-20^{\circ} \mathrm{C}$ & Suhu harian rata-rata $19{ }^{\circ} \mathrm{C}-26^{\circ} \mathrm{C}$ & sesuai \\
\hline 3 & PH tanah antara $5,5-6,5$ & PH tanah antara $5-6,5$ & sesuai \\
\hline 4 & $\begin{array}{l}\text { Curah hujan antara } 1.200-2.400 \\
\mathrm{~mm} / \text { tahun }\end{array}$ & $\begin{array}{l}\text { Curah hujan rata-rata } 2.150 \mathrm{~mm} / \text { tahun } \\
\mathrm{mm} / \text { bulan }\end{array}$ & sesuai \\
\hline
\end{tabular}

BPTP Jatim, 2018. Pedoman Umum Budidaya Bawang Putih 


\section{Analisis Usahatani dan $\mathbf{R} / \mathbf{C}$}

Penelitian ini dilakukan dilahan petani seluas 0,5 ha. Sesuai dengan hasil penelitian total produksi bawang putih yang diperoleh adalah sebesar 3.500 kg/luas lahan. Soekartawi (2006) mendefinisikan penerimaan usahatani adalah perkalian antara produksi dan harga jual. Berdasarkan hasil penelitian total penerimaan yang diperoleh $\mathrm{Rp}$ 42.000.000 yang diperoleh dari perkalian antara jumlah produksi yaitu $3.500 \mathrm{~kg}$ dikalikan dengan harga bawang putih saat itu yaitu $\mathrm{Rp} 12.000 / \mathrm{kg}$. Dengan total biaya yang dikeluarkan $\mathrm{Rp}$ 33.788.250. Pendapatan usahatani merupakan selisih antara penerimaan dengan biaya-biaya yang dikeluarkan untuk proses produksi. Total penerimaan sebesar Rp 42.000.000 dan total biaya sebesar $\mathrm{Rp}$ 33.788.250. Dengan demikian, maka total pendapatan yang diperoleh sebesar Rp 8.211.750.

Analisis R/C perlu dilakukan untuk mengetahui layak atau tidaknya usahatani yang dikelola oleh petani di daerah penelitian. R/C per luas lahan yang didapatkan pada penelitian ini adalah sebesar 1,24. R/C sebesar 1, 24 berarti bahwa setiap Rp 1.000.000,- modal yang diinvestasikan pada usahatani bawang putih yang dikelola oleh petani akan menghasilkan penerimaan sebesar $\mathrm{Rp}$
1.240.000,- yang berarti usahatani bawang putih secara ekonomi menguntungkan dan layak untuk diusahakan. Meskipun secara teoritis usahatani bawang putih layak diusahakan, tetapi kenyataan di lapangan bawang putih umbi sulit untuk berkembang. Hal ini disebabkan karena di Kecamatan Ciwidey terdapat beberapa komoditas pesaing yang memiliki nilai ekonomi lebih tinggi seperti seledri, bawang daun dan yang menjadi primadona saat ini yaitu bawang son atau bawang putih muda.

Tabel 4. Perbandingan nilai $\mathrm{R} / \mathrm{C}$ bawang putih umbi dengan komoditas lain di Kecamatan Ciwidey

\begin{tabular}{lll}
\hline No. & Komoditas & R/C \\
\hline 1. & Bawang putih muda (son) & 3,28 \\
2. & Bawang daun & 1,78 \\
3. & Seledri & 1,69 \\
4. & Bawang putih umbi & 1,24 \\
\hline \multicolumn{2}{l}{ Sumber: data primer diolah, 2019 }
\end{tabular}

\section{Analisis SWOT}

Matriks SWOT dibangun berdasarkan hasil analisis faktor-faktor strategis baik internal maupun eksternal yang terdiri atas faktor kekuatan, kelemahan, peluang dan ancaman. Dari faktor-faktor internal dan eksternal tersebut, maka digambarkan matrik SWOT, untuk mengetahui bagaimana peluang dan ancaman eksternal yang dihadapi oleh petani di Kecamatan Ciwidey dalam pengembangan usahatani bawang putih, 


\section{STRATEGI PENGEMBANGAN USAHATANI BAWANG PUTIH \\ DI KECAMATAN CIWIDEY KABUPATEN BANDUNG \\ Syam Ahmad Sopian, Lucyana Trimo}

dapat disesuaikan dengan kekuatan dan

kelemahan yang dimiliki.

\begin{tabular}{|c|c|c|}
\hline IFE & $\begin{array}{l}\text { STRENGHTS (S) } \\
\text { - Kondisi lingkungan } \\
\text { dan kesuburan tanah } \\
\text { - Potensi ketersediaan } \\
\text { lahan } \\
\text { - Potensi SDM pertanian } \\
\text { - Infrastruktur dan akses } \\
\text { ke pasar } \\
\text { - Reputasi ciwidey } \\
\text { sebagai penghasil } \\
\text { sayuran berkualitas }\end{array}$ & $\begin{array}{l}\text { WEAKNESS (W) } \\
\text { - Luas lahan garapan tergolong } \\
\text { sempit } \\
\text { - Modal terbatas } \\
\text { - Penguasaan petani terhadap } \\
\text { teknologi budidaya masih rendah } \\
\text { - Produktivitas rendah } \\
\text { - Performa bawang putih lokal di } \\
\text { pasaran kalah dengan bawang } \\
\text { putih impor } \\
\text { - Terdapat komoditas pesaing } \\
\text { dengan nilai ekonomi yang lebih } \\
\text { tinggi dibandingkan bawang putih } \\
\text { umbi, yaitu bawang putih muda }\end{array}$ \\
\hline $\begin{array}{l}\text { OPPORTUNITIES }(\mathbf{O}) \\
\text { - Dukungan pemerintah dalam } \\
\text { program swasembada bawang putih } \\
\text { - Permintaan bawang putih tinggi } \\
\text { - Harga bawang putih di pasaran tinggi }\end{array}$ & $\begin{array}{c}\text { STRATEGI S-O } \\
\text { Meningkatkan produksi } \\
\text { bawang putih }\end{array}$ & $\begin{array}{c}\text { STRATEGI W-O } \\
\text { Pemberdayaan petani bawang putih }\end{array}$ \\
\hline $\begin{array}{l}\text { THREATHS (T) } \\
\text { - Persaingan dengan bawang putih } \\
\text { impor } \\
\text { - Persaingan lahan dengan komoditas } \\
\text { lain yang bernilai ekonomi lebih } \\
\text { tinggi } \\
\text { - Serangan hama dan penyakit }\end{array}$ & $\begin{array}{l}\text { STRATEGI S-T } \\
\text { Meningkatkan daya } \\
\text { saing produk }\end{array}$ & $\begin{array}{c}\text { STRATEGI W-T } \\
\text { Memperkuat posisi usaha petani }\end{array}$ \\
\hline
\end{tabular}

Berdasarkan analisis matrik SWOT diperoleh hasil bahwa usahatani bawang putih di Kecamatan Ciwidey berada pada posisi kuadran II (dua) karena memiliki lebih banyak kelemahan, namun juga memiliki peluang yang tinggi untuk pengembangan. Sehingga strategi yang cocok untuk diterapkan adalah strategi WO, yaitu meminimalkan kelemahan yang dimiliki untuk memanfaatkan peluang yang ada.

\section{KESIMPULAN}

Berdasarkan hasil penelitian mengenai prospek pengembangan bawang putih di Kecamatan Ciwidey Kabupaten Bandung:

1. Dilihat dari kondisi lingkungan biofisik, Kecamatan Ciidey memiliki potensi untuk dilakukan pengembangan usahatani bawang putih. Kondisi lingkungan sesuai dengan syarat pertuumbuhan tanaman bawang putih.

2. Secara ekonomi, usahatani bawang putih di Kecamatan Ciwidey dapat dikatakan masih layak diusahakan dilihat dari nilai $\mathrm{R} / \mathrm{C}$ sebesar 1,24 yang artinya masih dapat memberikan keuntungan. Namun, kenyataan di lapangan terdapat komoditas lain yang biasa diusahakan 
petani karena memiliki nilai $\mathrm{R} / \mathrm{C}$ yang lebih besar, yaitu komoditas bawang putih muda. Hal ini tentu dapat menjadi ancaman bagi pengembangan bawang putih umbi di Kecamatan Ciwidey.

3. Berdasarkan hasil analisis SWOT yang diperoleh dari hasil usahatani bawang putih berada pada kuadran II, maka strategi yang sesuai untuk pengembangan usahatani bawang putih di Kecamatan Ciwidey adalah strategi W-O yaitu meminimalkan kelemahan yang dimiliki untuk memanfaatkan peluang yang ada.

Oleh karena itu, strategi yang tepat dan diutamakan dalam upaya pengembangan usahatani bawang putih di Kecamatan Ciwidey adalah dengan pemberdayaan petani bawang putih untuk menghasilkan bawang putih dengan produksi tinggi dan kualitas yang mampu bersaing dengan bawang putih impor yang nantinya berimbas kepada peningkatan nilai ekonomi bawang putih.

\section{DAFTAR PUSTAKA}

Badan Pusat Statistik. (2017). Luas Panen, Produksi dan Produktivitas Bawang Putih di Indonesia. BPS.

BPTP Jatim. (2018). Panduan Budidaya Bawang Putih. Balitbangtan. Kementan. Jakarta.

Kementerian Pertanian. (2018). Permentan RI ; Rekomendasi Impor Produk Hortikultura. Kementerian Pertanian. Jakarta.

Rahmi Ulfa. (2018). Analisis Usahatani Bawang Putih dan Permasalahannya di Nagari SalayoTanang Bukit Sileh Kecamatan Lembang Jaya Kabupaten Solok. Skripsi, Fakultas Pertanian. Universitas Andalas.

Soekartawi. (2006). Analisis Usahatani. Jakarta: Penerbit Universitas Indonesia.

Sugiyono. (2011). Desain Penelitian Kualitatif. Jakarta: Rajawali Pers. 